\section{An entomoepidemiological investigation of Chagas disease in the state of Ceará, Northeast Region of Brazil}

\author{
Investigação entomoepidemiológica da doença de \\ Chagas no Estado do Ceará, Nordeste do Brasil
}

\author{
Investigación entomoepidemiológica de la \\ enfermedad de Chagas en el estado de \\ Ceará, noreste de Brasil
}

\author{
Carolina Fausto de Souza Coutinho ${ }^{1}$ \\ Reinaldo Souza-Santos 2 \\ Natalia Faria Daflon Teixeira ${ }^{3}$ \\ Ingebourg Georg 4 \\ Taís Ferreira Gomes 3 \\ Marcio Neves Boia ${ }^{3}$ \\ Neilane Bertoni dos Reis 1 \\ Alexander de Oliveira Maia 3 \\ Marli Maria Lima ${ }^{3}$
}

\section{Resumo}

\footnotetext{
${ }^{1}$ Instituto de Comunicação e Informação Científica e Tecnológica em Saúde, Fundação Oswaldo Cruz, Rio de Janeiro, Brasil.

2 Escola Nacional de Saúde Pública Sergio Arouca,

Fundação Oswaldo Cruz, Rio de Janeiro, Brasil.

3 Instituto Oswaldo Cruz,

Fundação Oswaldo Cruz, Rio

de Janeiro, Brasil.

4 Instituto de Pesquisa

Clínica Evandro Chagas,

Fundação Oswaldo Cruz, Rio

de Janeiro, Brasil.

Correspondence

M. M. Lima

Laboratório de

Ecoepidemiologia da Doença de Chagas, Instituto Oswaldo

Cruz, Fundação Oswaldo

Cruz.

Av. Brasil 4365, Rio de

Janeiro, $R J$

21045-900, Brasil.

mmlima@ioc.fiocruz.br
}

\begin{abstract}
The seroprevalence of Chagas disease in humans and the presence of triatomines were investigated in a rural locality in the State of Ceará, Brazil, an historically endemic region. Approximately $80 \%$ of the surveyed residents agreed to undergo serological tests. Intradomestic and peridomestic environments were searched for triatomines in both the dry and rainy seasons. The prevalence rate of Chagas disease was $1.2 \%$ and the majority of individuals confirmed with the disease over 50 years of age. A total of 761 specimens of triatomines were captured, most of which were from colonies composed of nymphs and adult bugs, and the majority of specimens were obtained in the dry season. Triatoma brasiliensis was the predominant species. Analysis using light microscopy revealed that $28.6 \%$ of the insects were Trypanosoma cruzi positive. Results suggest that peridomestic man-made structures, such as animal shelters, improper storage of timber and uninhabited dwellings contribute to the high rate of triatomine infestation in the area.
\end{abstract}

Triatominae; Disease Vectors; Chagas Disease
A presença de triatomíneos e a soroprevalência da infecção chagásica humana foram investigadas em uma localidade rural do Estado do Ceará, Brasil, região endêmica histórica da doença de Chagas. Os triatomíneos foram pesquisados nos domicílios, nos períodos de seca e de chuva. A soroprevalência encontrada no período foi de 1,2\%, maior entre pessoas com mais de 50 anos de idade, e sem diferença significativa em relação ao sexo. Foram capturados 761 espécimes de triatomíneos, em colônias compostas de ninfas e insetos adultos, com predominância de Triatoma brasiliensis, especialmente no período de seca. O exame do conteúdo intestinal dos insetos revelou que 28,6\% eram Trypanosoma cruzi positivos. Os resultados sugerem que os abrigos de animais e armazenamento inadequado de materiais no peridomicílio, particularmente amontoados de madeiras, bem como moradias desabitadas, contribuem para o alto índice de infestação de triatomíneos na localidade.

Triatominae; Vetores de Doenças; Doença de Chagas; 


\section{Introduction}

The prevalence of Chagas disease among the total population of Brazil in the 1980s was estimated at $4.2 \% 1$. However, the successful control of the main vector of the disease Triatoma infestans, together with quality assurance control of blood banks and improvements in housing conditions in endemic regions have led to a sharp decline in the number of new cases of this disease in the last decade ${ }^{2}$. However, in regions where autochthonous triatomine species are common, the parasite-vector-reservoir-host interaction is often maintained when the health vigilance system fails. Since the decentralization of the Brazilian health system, native vector control measures have been the responsibility of municipal governments, which have not always achieved desired results due to operational and political difficulties and lack of financial resources. In regions where the wild triatomine species are predominant, the low residual effect of insecticides along with the degradation of the natural environment around cities facilitates house invasion and colonization by triatomines of human domiciles and outbuildings ${ }^{3}$. The focus of current prevention campaigns are native triatomine species in wild or peridomestic habitats, which are increasingly invading or reinvading both peridomicile and intradomicile areas in endemic regions as consequence of deforestation ${ }^{3}$. This phenomenon is characteristic not only of the State of Ceará, but also of other states in the Northeast Region of Brazil where T. infestans is not present. In these states the real threat of transmission of Trypanosoma cruzi comes from other peridomestic species such as, Triatoma brasiliensis, Triatoma pseudomaculata, Triatoma sordida and Panstrongylus megistus 3,4,5. Therefore, continuous surveillance measures are recommended to avoid the recrudescence of Chagas disease in this region.

With the aim of contributing to the improvement of triatomine control programs in this endemic region, this study investigates triatomine infestation in peridomicile and intradomicile areas and Chagas disease infection among local residents in a rural locality in an area impacted by human action in the Jaguaribe Valley, State of Ceará 6 .

\section{Materials and methods}

\section{Study area}

This study was conducted between 2008 and 2009 in the town of Miguel Pereira in the Municipality of Russas, State of Ceará, located 160km from the state capital Fortaleza. The municipality is located in the Jaguaribe River Valley in the Northeast Region of Brazil (456'25"S and 37058'33”W). The climate of this region is tropical hot and semi-arid with a rainy season occurring between January and April and dry season from May to December. Average annual rainfall is $857.7 \mathrm{~mm}$ (Ceará Institute of Research and Economic Strategy. http://www.ipece.ce.gov.br/publicacoes/perfil basico/index_perfil_basico.htm, accessed on 19/ Sep/2012). With respect to Chagas disease, studies show that historically this region has been one of the most affected areas in the State of Ceará, due to high rates of wild bug invasion facilitated by poor housing conditions ?

An exploratory study was conducted in Miguel Pereira, a rural locality situated on a floodplain $17 \mathrm{~km}$ from the town center, to ascertain the current distribution of triatomine species in the municipality. This locality was selected due to the high rate of triatomine infested dwellings according to a survey conducted in 2008 by the Municipal Health Department in conjunction with the Health Department of the State of Ceará. The locality comprises 471 dwellings, housing approximately 1,000 residents. As in most rural areas in this region, the population has the custom of extracting and storing timber, mainly from the carnauba palm, for the construction of houses and other structures in peridomestic areas such as fences, corrals, pigsties and chicken coops. The local environment has been greatly altered due to the increased felling of the carnauba palm and other tree species typical to the Caatinga to make way for agriculture and cattle raising and to provide firewood for local brick and roof tile factories.

\section{Chagas disease serological survey}

Serological screening for Chagas disease was carried out during visits to all 471 households. Finger prick blood samples were collected on filter paper (Watman 50, GE Healthcare, São Paulo, Brazil) from all residents (including children) present at the time of the visit who agreed to participate in the study. Blood samples were analyzed in the laboratory using indirect immunofluorescence assay (IFA) and ELISA (enzymelinked immunosorbent assay). To elucidate dubious results, peripheral venous blood samples were collected for serological testing using indirect immunofluorescence, ELISA, PCR (polymerase chain reaction), in vitro xenodiagnosis and hemoculture. Subjects that tested positive in at least two tests were confirmed as having Chagas disease. Furthermore, all individuals who 
tested positive in at least one of the tests were subject to a clinical evaluation and, electrocardiogram to confirm the disease. Confirmed cases were stratified by gender and age to calculate the prevalence of Chagas disease in the study population. Differences between gender and age were verified using the chi-square test at the $5 \%$ significance level. The blood tests were carried out at the Evandro Chagas Clinical Research Institute of the Oswaldo Cruz Foundation (IPEC/Fiocruz). The study was approved by the Fiocruz Ethics Research Committee (application n. 039/01).

\section{Investigation and capture of triatomines}

Triatomine infestation and infection rates were assessed using a convenience sample of 220 households where two bug capture sessions were carried out: one in the dry season and the other in the rainy season.

Domicile triatomine searches were carried out on five consecutive days in each season and were conducted by two people who captured the bugs using forceps. The following environments were investigated: houses (inside and outside); peridomestic areas within a 100 meters of the house containing manmade structures such as corrals, pigsties, chicken coops, animal shelters and woodpiles. The captured triatomines were kept in labeled plastic containers and forwarded to the laboratory for species identification and testing for T. cruzi infection. The presence of protozoa in insect feces was detected using a conventional light microscope $(400 \mathrm{x})$ considering the entire length of the cover slip.

The following entomological indicators recommended by the World Health Organization for Chagas disease control 8 were analyzed for both the dry and rainy season: (i) intradomicile and peridomicile infestation; (ii) indoor colonization; (iii) T. cruzi infection; and (iv) triatomine density. The chi-square test was used to verify differences in results obtained in the dry and rainy season and the student's t-test was used to analyze density. Data was analyzed using the R software version 2.10.1 (The R Foundation for Statistical Computing, Vienna, Austria; http://www.r-project.org) adopting a 5\% significance level.

\section{Results}

\section{Seroprevalence}

A total of 812 local residents were interviewed of which $642(79.1 \%)$ agreed to carry out blood tests. Prior to testing, four people declared that they were T. cruzi positive and had already been sub- mitted to treatment, which was later confirmed by the serological assays. Four other individuals tested positive in at least two different tests (one individual aged between 20 and 29 years and three individuals aged over 40 years). The human Chagas cases identified by this study did not show any family association (i.e. vertical transmission). Participants diagnosed with Chagas disease were given orientation with respect to treatment and monitoring and the Russas Secretary of Health was notified of the cases. The results of our investigation show that the prevalence rate of Chagas disease in Miguel Pereira was $1.2 \%$. No significant difference was found between genders (p > 0.05) (Table 1).

\section{Entomological survey}

Peridomestic triatomine infestation was detected in 40 of the 220 homes surveyed (18.2\%) and internal infestation was found in seven houses $(3.2 \%)$. A total of 761 triatomines were captured, consisting of the following species: T. brasiliensis (77.1\%); T. pseudomaculata (19.8\%); P. megistus (2.9\%); and Rhodnius nasutus $(0.1 \%)$. A total of 658 (86.5\%) triatomines were found in close proximity to houses, of which $73.3 \%$ were nymphs, $15.4 \%$ adult males and $11.4 \%$ adult females (Table 2). The majority of triatomines $(76.9 \%)$ were collected in the dry season, while $23.1 \%$ were collected in the rainy season. Internal infestation was detected in six houses in the dry season and three in the rainy season. The proportion of triatomines captured indoors during the dry season and rainy season was $14.2 \%$ and $11.4 \%$, respectively. However, this difference was not shown to be significant $(p>0.05)$. The infection rate of specimens captured indoors was significantly higher in the dry season than in the wet season $(71 \%$ and $10 \%$, respectively: $p$ $<0.05)$. As expected, most insects were found in the peridomicile areas $(86.5 \%)$ in both seasons. In the dry season and rainy season the proportion of bugs found in peridomestic manmade structures was $14.1 \%$ and $9.1 \%$, respectively. No significant difference was found $(\mathrm{p}<0.03)$. Infection with $T$. cruzi in bugs found in peridomicile areas was more frequent in the rainy season than in the dry season (29.9\% and $23 \%$, respectively). However, these differences were not significant $(\mathrm{p}<0.05)$.

A total of 103 bugs from six different $T$. brasiliensis colonies were captured inside houses in the dry and rainy seasons, most of which were nymphs (92.2\%), apart from one sole specimen of T. pseudomaculata. With respect to peridomestic environments, 658 (86.5\%) specimens of various species were obtained, of which $73.3 \%$ 
Table 1

Seroprevalence of Chagas disease confirmed by two or more different types of tests, stratified by sex and age, in Miguel Pereira, Russas, State of Ceará, Brazil, 2008 to 2009 .

\begin{tabular}{|c|c|c|c|c|c|c|c|c|c|}
\hline & \multicolumn{9}{|c|}{ Age group (years) } \\
\hline & $0-9$ & $10-19$ & $20-29$ & $30-39$ & $40-49$ & $50-59$ & $60-69$ & $\geq 70$ & Total \\
\hline \multicolumn{10}{|l|}{ Women } \\
\hline Interviewees & 62 & 80 & 58 & 55 & 47 & 59 & 23 & 39 & 423 \\
\hline Examined & 47 & 70 & 41 & 44 & 42 & 59 & 22 & 32 & 357 (84.4\%) \\
\hline Cases of Chagas disease & - & - & 1 & - & 1 & 3 & - & - & 5 \\
\hline Punctual prevalence (\%) & - & - & 2.4 & - & 2.4 & 5.1 & - & - & 1.4 \\
\hline \multicolumn{10}{|l|}{ Men } \\
\hline Interviewees & 47 & 76 & 57 & 56 & 64 & 37 & 25 & 27 & 389 \\
\hline Examined & 37 & 52 & 32 & 41 & 49 & 30 & 21 & 23 & $285(73.3 \%)$ \\
\hline Cases of Chagas disease & - & - & - & - & 1 & 2 & - & - & 3 \\
\hline Punctual prevalence (\%) & - & - & - & - & 2.0 & 6.6 & - & - & 1.1 \\
\hline \multicolumn{10}{|l|}{ Total } \\
\hline Cases of Chagas disease & - & - & 1 & - & 2 & 5 & - & - & 8 \\
\hline Total punctual prevalence (\%) & - & - & 1.4 & - & 2.2 & 5.6 & - & - & 1.2 \\
\hline
\end{tabular}

Table 2

Number of triatomines captured and natural infection rate by species, stage of development and capture environment, in Miguel Pereira, Russas, State of Ceará, Brazil, 2008 to 2009.

\begin{tabular}{|c|c|c|c|c|c|}
\hline Capture environments & Triatoma brasilienses & Triatoma pseudomaculata & Panstrongylus megistus & Rhodnius nastus * & Total \\
\hline \multicolumn{6}{|l|}{ Intradomicile areas } \\
\hline \multicolumn{6}{|l|}{ Nymphs } \\
\hline Captured (n) & 95 & - & - & - & 95 \\
\hline Infected (\%) & 57.3 & - & - & - & - \\
\hline \multicolumn{6}{|l|}{ Females } \\
\hline Captured (n) & 3 & 1 & - & - & 4 \\
\hline Infected (\%) & 66.7 & 0.0 & - & - & - \\
\hline \multicolumn{6}{|l|}{ Males } \\
\hline Captured (n) & 4 & - & - & - & 4 \\
\hline Infected (\%) & 33.3 & - & - & - & - \\
\hline \multicolumn{6}{|l|}{ Peridomicile areas } \\
\hline \multicolumn{6}{|l|}{ Nymphs } \\
\hline Captured (n) & 338 & 128 & 16 & - & 482 \\
\hline Infected (\%) & 21.2 & 41.1 & 73.3 & - & - \\
\hline \multicolumn{6}{|l|}{ Females } \\
\hline Captured (n) & 62 & 9 & 4 & - & 75 \\
\hline Infected (\%) & 10.2 & 55.6 & 50.0 & - & - \\
\hline \multicolumn{6}{|l|}{ Males } \\
\hline Captured (n) & 85 & 13 & 2 & 1 & 101 \\
\hline Infected (\%) & 9.0 & 15.4 & 50.0 & 100.0 & - \\
\hline \multicolumn{6}{|l|}{ Total } \\
\hline Captured (n) & 587 & 151 & 22 & 1 & 761 \\
\hline Infected (\%) & 23.7 & 39.5 & 66.7 & 100.0 & 28.6 \\
\hline
\end{tabular}

* One sole adult was caught. 
were nymphs, $15.4 \%$ adult males and $11.4 \%$ females, together with 60 colonies. The dominant species in these colonies was $T$. brasiliensis (59.1\%) (Table 3).

A total of $54(24.5 \%)$ of the 220 houses surveyed were uninhabited in both the dry season and rainy season and $77.7 \%$ of the residences surveyed had at least one man-made peridomicile structure. A total of 531 man-made structures were investigated, of which 48 (9\%) were infested.

At least one T. cruzi infected triatomine was found in $72.7 \%$ of the infested woodpiles. A total of 31 of the infested man-made structures (64.6\%) were infested by $T$. brasiliensis. Infestation of peridomestic structures by $T$. brasiliensis was most common in woodpiles (38.7\%) and goat/sheep corrals (22.6\%) (Table 4 ). Since $52.2 \%$ of T. pseudomaculata, $80 \%$ of P. megistus and the sole specimen of $R$. nasutus were also captured in this environment, it could be said that the triatomine species have a preference for woodpiles. With regard to cohabitation, T. brasiliensis and $T$. pseudomaculata were found together in 10 different types of environment, P. megistus and $T$. brasiliensis in one type of environment, and $P$. megistus and T. pseudomaculata in two types of environment. The presence of nymphs and eggs was detected in $85.4 \%$ of peridomicile annexes, and $56.1 \%$ of the nymphs were infected with T. cruzi.

With respect to entomological indicators, while infestation and colonization was significantly greater in the dry season, no significant difference was found with regard to natural infection (Table 5). Density was significantly higher during the dry period $(\underline{X}=2.66)$ than in the rainy season $(\underline{\mathrm{X}}=0.80)(\mathrm{p}<0.02)$.

Table 3

Number and size of colonies, by species, found in Miguel Pereira, Russas, State of Ceará, Brazil, 2008 to 2009.

\begin{tabular}{|c|c|c|c|c|c|c|}
\hline \multirow{3}{*}{$\begin{array}{l}\text { Specimens of triatomines per } \\
\text { colony }\end{array}$} & \multicolumn{6}{|c|}{ Number of colonies per species } \\
\hline & \multicolumn{2}{|c|}{ Triatoma brasiliensis } & \multicolumn{2}{|c|}{ Triatoma pseudomaculata } & \multicolumn{2}{|c|}{ Panstrongylus megistus } \\
\hline & Intradomicile & Peridomicile & Intradomicile & Peridomicile & Intradomicile & Peridomicile \\
\hline $1-10$ & 3 & 23 & - & 20 & - & 4 \\
\hline $11-20$ & 1 & 5 & - & 2 & - & - \\
\hline $21-30$ & - & 2 & - & 1 & - & - \\
\hline $31-40$ & 1 & 1 & - & - & - & - \\
\hline $71-80$ & 1 & 1 & - & - & - & - \\
\hline $81-90$ & - & 1 & - & - & - & - \\
\hline Total & 6 & 33 & - & 23 & - & 4 \\
\hline
\end{tabular}

Table 4

Type and number of man-made structures infested by triatomines and triatomines infected with Trypanosoma cruzi in Miguel

Pereira, Russas, State of Ceará, Brazil. 2008 to 2009.

\begin{tabular}{lccc}
\hline Type of manmade structure & Existent & Infested (\%) & Infected (\%) \\
\hline Wood piles & 136 & $22(16.2)$ & $16(72.7)$ \\
Brick/Roof Tile piles & 154 & $6(9.9)$ & $4(66.7)$ \\
Straw piles & 6 & 0 & 0 \\
Perch/Coop & 59 & $5(8.5)$ & $1(20.0)$ \\
Barn & 69 & $3(4.4)$ & $2(66.7)$ \\
Corral goat/Sheep & 32 & $7(21.9)$ & $5(71.4)$ \\
Corral cattle/Horses & 22 & 0 & 0 \\
Pigsties & 53 & $5(9.4)$ & $3(60.0)$ \\
Total & 531 & $48(9.0)$ & $31(64.6)$ \\
\hline
\end{tabular}


Table 5

Entomological indicators analyzed using the chi-square test in Miguel Pereira, Russas, State of Ceará, Brazil, 2008 to 2009.

\begin{tabular}{lccc}
\hline Entomological indicators & Dry season (\%) & Rainy season (\%) & $\begin{array}{c}\text { p-value } \\
\operatorname{Pr}(|Z|>|z|)\end{array}$ \\
\hline Domiciliar infestation & & 10.5 & 0.0020 \\
Domiciliar colonization & 16.8 & 8.2 & 0.0000 \\
Natural infection by Trypanosoma cruzi & 15.0 & 27.6 & 0.6542 \\
\hline
\end{tabular}

\section{Discussion}

The prevalence rate of Chagas disease in the human population of Miguel Pereira was lower than the national prevalence rate in 1980 estimated at $4.2 \% 1$. The rate was also lower than rates in 2000 described in four villages in the municipality of Jaguaruana (3.1\%), located close to Russas 9 . A comparison with data for the State of Ceará from the national serological survey carried out between 1975 and $1980{ }^{1}$ reveals an increase in seroprevalence of T. cruzi infection from 0.8 to $1.2 \%$. However, it should be noted that our data is based on a single location and may differ from statewide estimates.

Prevalence rates in Miguel Pereira ranged from $1.4 \%$, among young adults aged between 20 and 29 years, and 5.6\%, among adults aged between 50 and 59 years. No cases were detected among children and teenagers, indicating that transmission of the disease has possibly subsided in the region, despite the high levels of insect infestation and T. cruzi infection. Currently, the Northeast Region of Brazil is the most prolific Chagas disease endemic area in the country, and has become a dispersal area for native triatomines such as T. brasiliensis and T. pseudomaculata 10 , which currently present the greatest challenge for reducing the transmission of the disease in Brazil. Traditional chemical insecticide spraying has not proved to be very effective since the main habitat of the bugs is in the wild and the ephemeral effect of insecticides means that re-infestation of houses is common shortly after spraying 11,12 .

Our findings regarding the dry and rainy seasons point to significant differences in infestation and triatomine colonization between seasons. These results are corroborated by other studies that reported higher infection rates and colonization during the dry season $13,14,15$. This disparity highlights the need for further longitudinal studies to define optimum timing for vector control insecticide application.
T. brasiliensis and T. pseudomaculata are also of concern in the Northeast Region because they are often more abundant than other species, infesting both intradomestic and peridomestic environments, and are characterized by high prevalence of natural T. cruzi infection 16,17. T. brasiliensis was the most abundant species in this study, followed by T. pseudomaculata, $P$. megistus and $R$. nasutus, the latter of which was practically absent from households. T. brasiliensis showed the greatest spatial distribution and capacity for domicile infestation and colonization 17,18. However, according to Silveira et al. 19, T. pseudomaculata may colonize indoors when in greater numbers and take over from T. brasiliensis. In fact, our study found that certain manmade structures were cohabitated by both species, possibly suggesting that T. pseudomaculata is gradually becoming dominant 20 .

It is known that each genus prefers different natural ecotopes. For example, Rhodnius is more commonly associated with palm trees, Panstrongylus with animal burrows and tree cavities and Triatoma with rocky outcrops, caves and rodent burrows 23 . However, in and around houses, triatomines may prefer other types of shelter and peridomicile areas offer a number of options of hosts and shelter, besides possessing the ideal microclimate for successful population development 24 . However, some artificial ecotopes may be more attractive to some species than others and studies carried out in neighboring municipalities showed higher triatomine infestation in animal shelters such as goat/sheep corrals and chicken coops 17,25. Sarquis et al. 17 showed an association between T. brasiliensis and roof tile and brick piles, suggesting that such ecotopes may resemble its natural ecotope. Our findings show that the highest infestation and natural T. cruzi infection rates in all triatomine species occurred in woodpiles. Besides providing shelter for triatomines in the spaces and cracks, food is also abundant in this type of ecotope since it is riddled with burrows of small animals such as rodents 
and marsupials, which are $T$. cruzi reservoirs. In Miguel Pereira, as in most rural communities, residents extract timber from the natural environment for construction of houses, animal shelters and fences. This wood is often stored for long periods of time in peridomicile areas, inevitably serving as shelters for synanthropic animals 7 .

Our results show that the woodpiles are the main cause of the high triatomine infestation and infection rates in the region, since this ecotope harbors large, well established colonies consisting of T. cruzi infected adults and different instar nymphs. It has been suggested that the increase in the triatomine infestation and dissemination rates may be due to environmental factors, such as vegetation type, food availability, and use of wood for construction 26. Residents of Miguel Pereira reported the presence of small, wild mammals such as opossums (Didelphis albiventris), cavies (Galia spixii) and rats in close proximity to their houses. These synanthropic animals often invade peridomicile areas using man-made structures, principally wood piles, as shelters, implying that triatomine T. cruzi in- fection may be taking place in the domestic environment. These small rodents have also been noted in the neighboring town of Jaguaruana 15. Further studies on these insects' food sources and the distribution of synanthropic animals are needed to understand the disease infection cycle in the locality. As described by Xavier et al. 26, human impact on the local environment may lead to an increase in the T. cruzi infection rate in certain mammal species, reinforcing the need for detailed information of the specific local conditions to effectively assess the potential disease risk factors.

The results of this study emphasize the need to develop further studies in endemic areas to determine the specific local factors associated with infestation and infection and relative appropriate control measures. Insecticide control and educational campaigns geared towards resident awareness concerning the dangers of triatomine contact together with improvements in intradomestic and peridomestic environments are essential steps for Chagas disease control in Miguel Pereira.

\section{Resumen}

Se investigó la presencia de insectos y seroprevalencia en la infección humana por Trypanosoma cruzi, en un área rural del estado de Ceará, Brasil, región endémica histórica de la enfermedad Chagas. Se informó sobre la presencia de insectos en los hogares durante los períodos de sequía y lluvia. La seroprevalencia en el período fue un 1,2\%, mayor entre las personas de más de 50 años de edad, y no hubo diferencias significativas en relación al sexo. Se capturaron 761 ejemplares de insectos en colonias compuestas por ninfas y adultos de insectos, principalmente, Triatoma brasiliensis, especialmente durante la estación seca. El examen del contenido intestinal de los insectos reveló que un 28,6\% eran $\mathrm{T}$. cruzi positivo. Los resultados sugieren que los refugios de animales y el almacenamiento inadecuado de materiales fuera del hogar, especialmente pilas de madera y casas deshabitadas, contribuyen a la alta tasa de infestación de insectos en la localidad.

Triatominae; Vectores de Enfermedades; Enfermedad de Chagas 


\section{Contributors}

C. F. S. Coutinho and R. Souza-Santos and M. M. Lima prepared the proposal, wrote the article, and planned, scheduled, and conducted data analysis. N. F. D. Teixeira contributed to the field work, supervised the creation of the database and contributed to discussions regarding this study and article. I. Georg and T. F. Gomes conducted the diagnostic tests and contributed to discussions regarding this study and article. M. N. Boia conducted the clinical tests and contributed to discussions regarding this study and article. N. B. Reis conducted statistical analysis and contributed to discussions regarding this study and article. A. O. Maia contributed to the field work and contributed to discussions regarding this study and article.

\section{Acknowledgments}

We are grateful to the Ceará State Secretary of Health and the Russas Municipal Secretary of Health for their technical assistance, transport and use of facilities. We are also grateful to Marcelo Rojas Burgoa, Francineudo Nogueira de Oliveira and Carlos Jorge de Lima, for their invaluable assistance with fieldwork, and to Mitchell R. Lishon for revising the English version of this article. This study was funded by Capes.

\section{References}

1. Camargo ME, Silva GR, Castilho AC. Inquérito sorológico da prevalência de infecção chagásica no Brasil, 1975/1980. Rev Inst Med Trop São Paulo 1984; 26:192-236.

2. World Health Organization. Chagas disease: control and elimination. Geneva: World Health Organization; 2008.

3. Dias JCP. Epidemiologia. In: Trypanosoma cruzi e doença de Chagas. 2a Ed. Rio de Janeiro: Editora Guanabara Koogan; 2000. p. 48-74.

4. Ramos AN, Carvalho DM. Os diferentes significados da certificação conferida ao Brasil como estando livre da doença de Chagas. Cad Saúde Pública 2001; 17:1403-12.

5. Dias JP, Bastos C, Araújo E, Mascarenhas AV, Martins Netto E, Grassi F, et al. Acute Chagas disease outbreak associated with oral transmission. Rev Soc Bras Med Trop 2008; 41:269-300.
6. Lima MM, Sarquis O, Oliveira TG, Gomes TF Coutinho C, Daflon-Teixeira NF, et al. Investigation of Chagas disease in four peri urban areas in Northeastern Brazil: epidemiologic survey in man, vectors and non-human hosts and reservoirs. Trans R Soc Trop Med Hyg 2012; 106:143-9.

7. Alencar JE, Almeida YM, Freitas LM, Santos AR. Estudos sobre a epidemiologia da doença de Chagas no Estado do Ceará - Brasil. VI - Estudos em uma micro-área de Russas. Rev Soc Bras Med Trop 1977; 11:1-12.

8. World Health Organization. Control of Chagas disease. Geneva: World Health Organization; 1991 (Technical Report Series, 811).

9. Borges-Pereira J, Sarquis O, Zauza PL, Britto C, Lima MM. Epidemiologia da doença de Chagas em quatro localidades rurais de Jaguaruana, Estado do Ceará. Soroprevalência da infecção, parasitemia e aspectos clínicos. Rev Soc Bras Med Trop 2008; 41:345-51. 
10. Dias JCP. Southern Cone Initiative for the elimination of domestic populations of Triatoma infestans and the interruption of transfusional Chagas disease. Historical aspects, present situation and perspectives. Mem Inst Oswaldo Cruz 2007; 102:11-8.

11. Diotaiuti L, Faria Filho OF, Carneiro FCF, Dias JCP, Pires HHR, Schofield CJ. Aspectos operacionais do controle do Triatoma brasiliensis. Cad Saúde Pública 2000; 16 Suppl 2:61-7.

12. Barbu C, Dumonteil E, Gourbiere S. Optimization of control strategies for non-domiciliated Triatoma dimidata, Chagas disease vector in the Yucatán peninsula, Mexico. PLoS Neg Trop Dis 2009; 3:e416.

13. Gurgel-Gonçalves R, Cuba CAC. Population structure of Rhodnius neglectus Lent and Psammolestes tertius Lent and Jurberg (Hemiptera, Reduviidae) in bird nests (Fumariidae) on Mauritia flexuosa palm trees in Federal District of Brazil. Rev Bras Zool 2007; 24:157-63.

14. Gómez-Hernández C, Rezende-Oliveira K, Zárate AC, Zárate EC, Trujillo-Contreras F, Ramirez LE. Prevalência de triatomíneos (Hemiptera: Reduviidae: Triatominae) infectados por Trypanosoma cruzi: sazonalidade e distribuição na região Ciénega do Estado de Jalisco, México. Rev Soc Bras Med Trop 2008; 41:257-62.

15. Lima MM, Coutinho CF, Gomes TF, Oliveira TG, Duarte R, Borges-Pereira J, et al. Risk presented by Copernicia prunifera palm trees in the Rhodnius nasutus distribution in a Chagas disease-endemic area of the Brazilian northeast. Am J Trop Med Hyg 2008; 79:750-4.

16. Costa J, Almeida CE, Dotson EM, Lins A, Vinhaes M, Silveira AC, et al. The epidemiologic importance of Triatoma brasiliensis as a Chagas disease vector in Brazil: a revision of domiciliary captures during 1993-1999. Mem Inst Oswaldo Cruz 2003; 98:443-9.

17. Sarquis O, Sposina R, Oliveira TG, MacCord JR, Cabello PH, Borges-Pereira J, et al. Aspects of peridomiciliar ecotopes in rural areas of Northeastern Brazil associated to triatomine (Hemiptera, Reduviidae) infestation, vectors of Chagas disease. Mem Inst Oswaldo Cruz 2006; 101:143-7.
18. Alencar JE. História natural da doença de Chagas no Estado do Ceará. Fortaleza: Imprensa Universitária da Universidade Federal do Ceará; 1987.

19. Silveira AC, Vinhaes MC, Lira E, Araújo E. O controle de Triatoma brasiliensis e Triatoma pseudomaculata. Brasília: Organização Pan-Americana da Saúde; 2001.

20. Dias JCP, Diotaiuti LG. IWHO/TDR Technical report n. 811: small correction, proposal. Rev Soc Bras Med Trop 1998; 31:582-3.

21. Gaunt M, Miles M. The ecotopes and evolution of triatomine bugs (Triatominae) and their associated trypanosomes. Mem Inst Oswaldo Cruz 2000; 95:557-65

22. Cecere MC, Vasquez-Prokopec GM, Gürtler RE, Kitron U. Spatio-temporal analysis of reinfestation by Triatoma infestans (Hemiptera: Reduviidae) following insecticide spraying in a rural community in northwestern Argentina. Am J Trop Med Hyg 2004; 71:803-10.

23. Oliveira-Lima JW, Faria Filho OF, Vieira JBF, Gadelha FV, Oliveira Filho AM. Alterações do peridomicílio e suas implicações para o controle de Triatoma brasiliensis. Cad Saúde Pública 2000; 16 Suppl 2:75-81.

24. Coutinho CFS, Souza-Santos R, Lima MM. Combining geospatial analysis and exploratory study of triatomine ecology to evaluate the risk of Chagas disease in a rural locality. Acta Tropica 2002; 121:30-3.

25. Freitas SPC, Freitas ALC, Prazeres SM, Gonçalves TCM. Influência de hábitos antrópicos na dispersão de Triatoma pseudomaculata Corrêa \& Espínola, 1964, através de Mimosa tenuiflora (Willdenow) (Mimosaceae) no Estado do Ceará, Brasil. Cad Saúde Pública 2004; 20:333-6.

26. Xavier SC, Roque ALR, Lima VS, Monteiro KJL, Otaviano JCR, Silva LFCF, et al. Lower richness of small wild mammal species and Chagas disease risk. PLoS Negl Trop Dis 2012; 6:1-11.

Submitted on 10/Dec/2012

Final version resubmitted on 24/Aug/2013

Approved on 10/Oct/2013 